J. Clin. Chem. Clin. Biochem.

Vol. 17, 1979, pp. 299-302

\title{
Monitoring of Serum Theophylline Concentrations by a Fully Mechanized Enzyme Immunoassay (EMIT)
}

\author{
By M. Oellerich, G. W. Sybrecht and R. Haeckel \\ Technical Assistance: I. Isberner and H. H. Ripke
}

Institut für Klinische Chemie und Department Innere Medizin, Medizinische Hochschule Hannover

(Received November 11, 1978/February 12, 1979)

Summary: An evaluation of an enzyme immunoassay for the determination of theophylline in serum (EMIT, Syva Corp.) is presented. The EMIT assay was fully mechanized by the use of an Eppendorf analyzer 5010. The precision of this enzyme immunoassay was satisfactory (coefficients of variation from day to day ranged from 5-6\%). The EMIT assay proved to be specific, rapid and easy to perform. A comparison of the results obtained by EMIT and ultraviolet spectrophotometry in a series of 100 patients showed a good correlation between both methods.

\section{Überwachung der Theophyllinkonzentration im Serum mit einem vollmechanisierten Enzymimmunotest (EMIT)}

Zusammenfassung: Es wird über die Erprobung eines Enzymimmunotests zur Bestimmung von Theophyllin im Serum (EMIT, Syva Corp.) berichtet. Der EMIT-Test wurde mit Hilfe eines Eppendorf Enzymautomaten 5010 vollmechanisiert. Die Präzision dieses Enzymimmunotests war zufriedenstellend (die Variationskoeffizienten von Tag zu Tag lagen bei 5-6\%). Der EMIT-Test erwies sich als spezifisch sowie rasch und einfach durchführbar. Ein Vergleich der Ergebnisse, welche mit EMIT und einer UV-Methode bei einer Serie von 100 Patienten erhalten wurden, ergab eine gute Ubereinstimmung beider Verfahren.

\section{Introduction}

There is an increasing demand for rapid and reliable assays for the determination of serum levels of drugs, which have a narrow therapeutic range, and/or dangerous side effects, and for which considerable differences of pharmacokinetics between individuals are well documented. Enzyme immunoasșays have proved useful for routine monitoring of serum levels of various antiepileptic drugs and digoxin, and have recently gained increasing importance $(1,2)$.

Theophylline has been used for many years in the treatment of asthma (3) and for treating apnoea in premature infants (4). It has been demonstrated recently that the dosage of theophylline, based on a widely used body weight-derived formula (5), is unreliable and can be dangerous $(6,7)$, as there is a wide variation in the rate of metabolism of this compound (8). Patients with hepatic disease such as liver cirrhosis, show a slow and variable metabolism of theophylline, as about ninety percent of this drug is metabolized in the liver (9). Deaths from toxic theophylline concentrations have been observed with patients receiving therapeutic doses of the drug (10). The early detection of theophylline overdosage by clinical symptoms, however, may often be difficult, because typical signs like tachycardia or nausea are usually present in patients with respiratory distress due to the underlying disease. Furthermore, patients with toxic theophylline levels may develop seizures without preceding adverse effects (10).

Monitoring of serum theophylline levels has therefore been increasingly recommended in recent years ( 7 , 11-15). Usually, serum levels of theophylline between 10 and $20 \mathrm{mg} / \mathrm{l}$ provide substantial improvements in pulmonary function with minimal toxicity (8). In premature infants, serum concentrations of 6 to $11 \mathrm{mg} / \mathrm{l}$ are necessary to control apnoeic spells (11).

The present study presents an evaluation of an homogeneous enzyme immunoassay for the determination of theophylline (16), mechanized by means of an Eppendorf analyzer 5010 .

\section{Material and Methods}

Origin of specimens

Serum samples $(n=130)$ containing theophylline were obtained from patients with obstructive lung disease. If theophylline was administered by intravenous infusion, blood samples were drawn from the cubital vein of the contralateral arm. During oral maintenance therapy blood specimens were taken as recom- 
mended (7) either prior to the next dose or 2-4 hours afterwards.

\section{Materials}

The reagents for the enzyme immunoassay (EMIT), ammonium sulfate, chloroform, hexane, caffeine, xanthine, hypoxanthine, xanthosine, uric acid and urea were obtained from E. Merck (D-6100 Darmstadt), theophylline and paraxanthine from Sigma (D-8021 Taufkirchen), theobromine from Synochem (D-2000 Hamburg), 1,3-dimethyl-xanthine-7-acetic 7-( $\beta$ dimethyl-aminoethoxy)-flavone from Voigt (D-6250 Limburg), 7-( $\beta$-hydroxyethyl)-theophylline and 7-dihydroxypropyl-theophylline from Benechemie (D-8000 München), phenobarbital from Krewel (D-5208 Eitorf), phenytoin from Nordmark (D-2000 Hamburg), proxyphylline from Deutsche Pharmacia (D-7800 Freiburg), salbutamol from Glaxo (D-2060 Bad Oldesloe), terbutaline from Astra Chemicals (D-2000 Wedel), allopurinol from Ratiopharm (D-7902 Blaubeuren) and sulfmethoxazole from Hoffmann-La Roche (D-7889 GrenzachWyhlen).

\section{Enzyme immunoassay (EMIT)}

The original procedure of the EMIT theophylline assay was fully mechanized by adapting this test to the Eppendorf analyzer 5010 (Eppendorf, D-2000 Hamburg) in the same way as previously described for the EMIT phenobarbital and phenytoin assays (1).

\section{Ultraviolet spectrophotometry}

Ultraviolet spectrophotometry of theophylline in serum was performed by a procedure discribed by Schwertner et al (17) using a DMR 21 double beam recording spectrophotometer (C. Zeiss, D-7082 Oberkochen).

\section{Substrate determinations}

Creatinine was measured in serum after tungstate precipation of protein and a Fuller's earth adsorption procedure (18). Uric acid was determined by the aldehyde dehydrogenase method (19) (Human GmbH, D-6204 Taunusstein, cat. No H 1001) using an Abbott bichromatic analyzer ABA-100.

\section{Results and Discussion}

\section{Precision}

The coefficients of variation from day to day were 5-6\% with EMIT, and 6-12\% with ultraviolet spectrophotometry (tab. 1). These precision data refer to mean values of duplicate determinations.

Tab. 1. The precision from day to day of EMIT and an ultraviolet spectrophotometric method for the determination of theophylline in serum. Assays were performed in duplicates on various days as indicated, and the mean values were used for calculation of the precision.

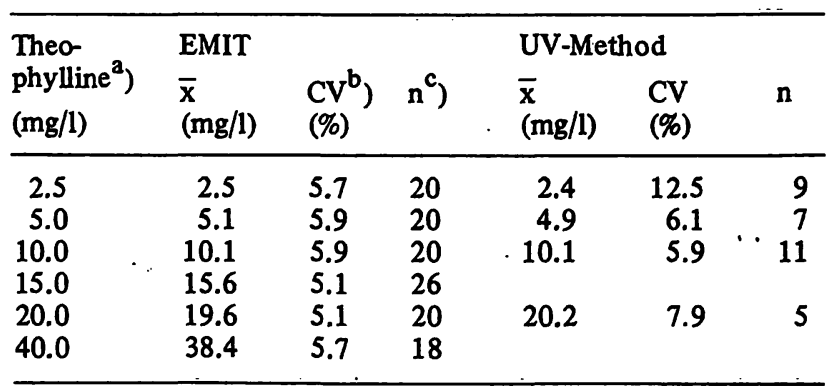

a) Calibrators (Syva) and drug-free serum samples spiked with theophylline.

b) Mean value $(\overline{\bar{x}}) \cdot$ with coefficient of variation

c) Number of days

\section{Accuracy}

The results for the recovery of theophylline by EMIT are shown in table 2 . The recovery of theophylline added to drug-free pooled human serum ranged from $97-102 \%$.

Furthermore the theophylline concentration was measured by EMIT and ultraviolet spectrophotometry in serum samples from 130 patients. However in nine of these specimens the theophylline concentration could not be determined by the ultraviolet method as the uv spectra were distorted by extraneous overlapping peaks due to interfering substances.

In a further 21 samples the theophylline concentration could not be measured by EMIT as it was below $2.5 \mathrm{mg} / \mathrm{l}$. In three of these cases the uv method, however, gave theophylline values between 3.6 and $8.0 \mathrm{mg} / \mathrm{l}$ presumably due to interference of proxyphylline and/or salbutamol. The absorption maximum of proxyphylline $(273 \mathrm{~nm})$ and salbutamol $(276 \mathrm{~nm})$ is very close to that of theophylline (274 nm).

The least-squares regression analysis of the results obtained with the remaining 100 serum samples showed the slope of the line to be 1.01 (fig. 1). The value of the

Tab. 2. The recovery of theophylline by EMIT in spiked serum samples. Determinations were performed in duplicate on eight days $(n=16)$

\begin{tabular}{lcc}
\hline $\begin{array}{l}\text { Theophylline } \\
\text { weighed in } \\
\text { (mg/l) }\end{array}$ & $\begin{array}{r}\text { found } \\
(\mathrm{mg} / \mathrm{l})\end{array}$ & Recovery \\
\hline 5.0 & 5.1 & $(\%)$ \\
10.0 & 9.7 & 102 \\
15.0 & 15.1 & 97 \\
25.0 & 25.3 & 101 \\
30.0 & 29.8 & 101 \\
35.0 & 35.2 & 99 \\
\hline
\end{tabular}

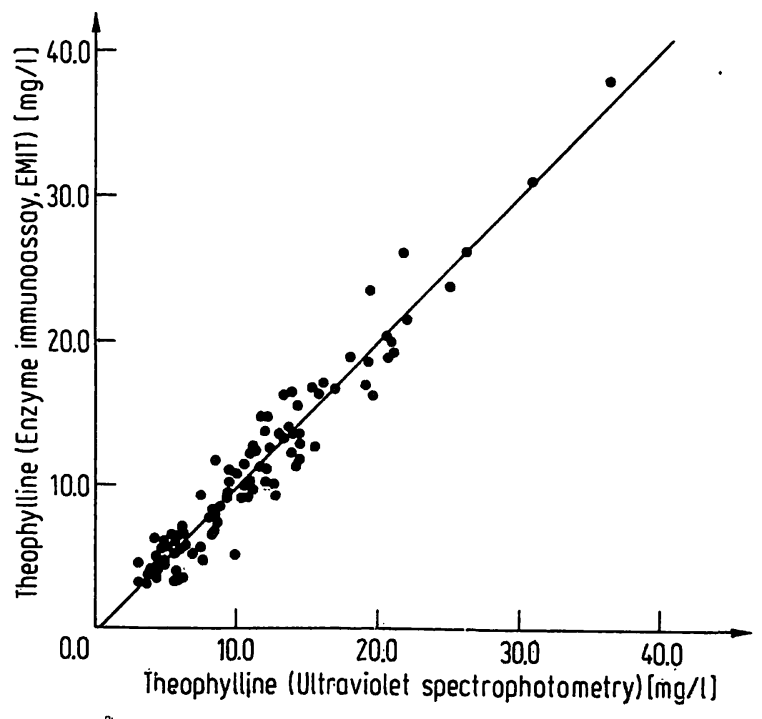

Fig. 1. Serum theophylline concentrations as measured by EMIT and ultraviolet spectrophotometry $(\mathrm{n}=100)$.

Slope: 1.01 , intercept: $-0.38 \mathrm{mg} / 1$, correlation coefficient: 0.969 . 
intercept was $-0.38 \mathrm{mg} / \mathrm{l}$. Both methods correlated well (coefficient of correlation: $r=0.969$ ). The mean value of the results of the ultraviolet spectrophotometric method was $11.1 \pm 6.3 \mathrm{mg} / 1$ and that of the results obtained by EMIT $10.9 \pm 6.6 \mathrm{mg} / \mathrm{l}$. The $\mathrm{t}$-value was $1.35(\mathrm{p}>0.05)$.

Deviations of more than $30 \%$ between the results determined by EMIT and ultraviolet spectrophotometry occurred with 8 out of these 100 samples. In five of these cases the discrepancies were reproducible. With four of these specimens the uv method yielded higher results than EMIT. These samples were obtained from patients who received salbutamol, $\beta$-hydroxyethyltheophylline, trimethoprim and sulfamethoxazole in addition to theophylline. These substances show absorption maxima between 257 and $276 \mathrm{~nm}$, which are near to that of theophylline. Therefore it appears, that these compounds caused the deviations observed by an interference in the uv-method. With only one of these five samples the uv-method yielded a lower result than EMIT.

Our results are in agreement with the reported satisfactory correlation of EMIT with ultraviolet spectrophotometric methods (20-22), high pressure liquid chromatography (21-23) and radioimmunoassay (22).

\section{Specificity}

The specificity of the EMIT assay was tested by the determination of the cross-reactivity of drugs structurally related to theophylline and various other compounds. The EMIT assay appeared to be highly specific, as none of the substances tested (tab. 3 ) showed a noticeable cross-reaction. According to the manufacturer's crossreactivity list (24) the major known metabolites of theophylline (25), 1,3-dimethyluric acid, 3-methylxanthine and 1-methyluric acid do not significantly cross react in this assay. Of the two further possible metabolites, 3-methyluric acid and 1-methylxanthine, only the latter showed a marked cross reaction at concentrations above $10 \mathrm{mg} / \mathrm{l}$ (24).

No positive results were obtained with serum samples from patients $(n=20)$ with renal insufficiency, receiving drugs other than theophylline (tab. 4).

\section{Interferences}

Bilinubin concentrations up to $600 \mu \mathrm{mol} / \mathrm{l}$ and haemoglobin concentrations up to $10 \mathrm{~g} / \mathrm{l}$ did not affect the results of this assay. Triglyceride concentrations up to $4.0 \mathrm{mmol} / 1$ showed no interference.

\section{Practicability and costs}

The EMIT assay has the advantage that it can be easily mechanized. Adaptations to various analyzers such as the Abbott Bichromatic Analyzer (ABA 100) (21), Rotochem II (26) and KA-150 Kinetic Analyżer (20)
Tab. 3. Cross-reactivity of various substances in serum ${ }^{a}$ ) with the EMIT theophylline assay.

\begin{tabular}{|c|c|}
\hline Compound & $\left.\mathrm{mg} / \mathrm{l}^{\mathrm{b}}\right)$ \\
\hline $\begin{array}{l}\text { Theophylline (1,3-dimethylxanthine) } \\
\text { Theobromine (3,7-dimethylxanthine) } \\
\text { Paraxanthine (1,7-dimethylxanthine) } \\
\text { Caffeine (1,3,7-trimethylxanthine) } \\
\text { 1,3-dimethyl-xanthine-7-acetic } \\
\text { 7-( } \beta \text {-dimethyl-aminoethoxy)-flavone } \\
\text { 7-( } \beta \text {-Hydroxyethyl)-1,3-dimethylxanthine } \\
\text { Diprophylline } \\
\text { (7-(2,3-Dihydroxypropyl)-1,3-dimethylxanthine) } \\
\text { Proxyphylline } \\
\text { (7-(2-Hydroxypropyl)-1,3-dimethylxanthine) } \\
\text { Xanthine } \\
\text { Hypoxanthine } \\
\text { Xanthosine } \\
\text { Uric acid } \\
\text { Urea } \\
\text { Phenobarbital } \\
\text { Phenytoin } \\
\text { Terbutaline } \\
\text { Salbutamol } \\
\text { Allopurinol } \\
\text { Sulphamethoxazole }\end{array}$ & $\begin{array}{r}>500 \\
>500 \\
>500 \\
>500 \\
>500 \\
>5000 \\
>500 \\
>500 \\
>500 \\
>500 \\
>500 \\
>500\end{array}$ \\
\hline
\end{tabular}

a) substances were added to drug-free pooled human serum.

b) concentrations exerting an absorbance equivalent to $2.5 \mathrm{mg} / 1$ theophylline.

Tab. 4. Drugs showing no cross-reaction in the EMIT theophylline assay. Serum samples $(n=20)$ were obtained from patients with renal insufficiency, taking the drugs listed below (mean value of serum creatinine concentrations $\bar{x}=464 \mu \mathrm{mol} / 1$ (range $119-1233 \mu \mathrm{mol} / \mathrm{l})$ and of uric acid concentrations $\overline{\mathrm{x}}=434 \mu \mathrm{mol} / \mathrm{l}$ (range 139-717 $\mu \mathrm{mol} / \mathrm{l}$ )

\begin{tabular}{|c|c|c|}
\hline Compound & Trade name & $\begin{array}{l}\text { Dosage } \\
\text { (mg/day) }\end{array}$ \\
\hline 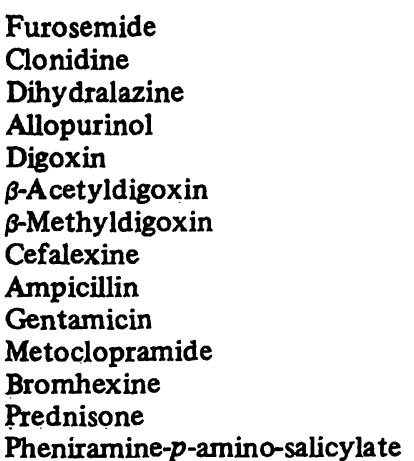 & $\begin{array}{l}\text { Lasix } \\
\text { Catapresan } \\
\text { Nepresol } \\
\text { Allopurinol } \\
\text { Lanicor } \\
\text { Novodigal mite } \\
\text { Lanitop } \\
\text { Oracef } \\
\text { Binotal } \\
\text { Refobacin } \\
\text { Paspertin } \\
\text { Bisolvon } \\
\text { Decortin } \\
\text { Avil }\end{array}$ & $\begin{array}{l}1000 \\
1.2 \\
100 \\
600 \\
0.25 \\
0.1 \\
0.1 \\
3000 \\
4000 \\
40 \\
30 \\
24 \\
10 \\
150\end{array}$ \\
\hline
\end{tabular}

have been reported. In contrast to other procedures, such as ultraviolet spectrophotometry, the EMIT method requires less time and sample volume. With our fully mechanized modification of the EMIT assay only $10 \mu \mathrm{l}$ of serum are necessary per theophylline determination, and about 30 patient samples can be analyzed (duplicate determinations) within 90 minutes. A single theophylline determination for emergency situations 
Tab. 5. Comparison of the costs of a quantitative determination of theophylline by an ultraviolet spectrophotometric method and EMIT adapted to the Eppendorf analyzer 5010.

\begin{tabular}{|c|c|c|c|c|c|c|c|}
\hline \multirow[t]{2}{*}{ Costs } & & \multicolumn{3}{|l|}{ EMIT } & \multicolumn{3}{|c|}{ UV-Spectrophotometry } \\
\hline & & $\left.n^{a}\right)=1$ & $\mathrm{n}=10$ & $\mathrm{n}=\mathbf{3 0}$ & $n=1$ & $\mathrm{n}=10$ & $\mathrm{n}=30$ \\
\hline Technician time $^{b}$ & DM & 12.00 & 1.50 & 0.80 & 51.00 & 14.40 & 13.00 \\
\hline $\begin{array}{l}\text { Reagents, standards, control sera and } \\
\text { pertinent supplies }\end{array}$ & $\mathrm{DM}$ & 77.28 & 19.35 & 13.39 & 17.84 & 4.31 & 3.13 \\
\hline Total & DM & 89.28 & 20.85 & 14.19 & 68.84 & 18.71 & 16.13 \\
\hline
\end{tabular}

a) $n=$ number of specimens per series b) costs per minute technician time $0.60 \mathrm{DM}$ (27).

takes about 40 minutes, as a new calibration curve has to be prepared with every run.

The costs for a theophylline determination including standards, control sera, reagents, pertinent supplies and technician time are about 21 DM per EMIT test and about $19 \mathrm{DM}$ with the uv-method, for a series of 10 samples (duplicate determinations). A single theophylline determination is much more expensive (tab. 5).

\section{Conclusion}

Compared with the ultraviolet spectrophotometric method, the EMIT theophylline assay showed a distinctly better specificity and practicability. Furthermore the EMIT assay could be easily mechanized and proved to be rapid and reliable. The results of our study showed the EMIT technique to be well suited for monitoring serum theophylline levels.

\section{References}

1. Oellerich, M., Külpmann, W. R. \& Haeckel, R. (1977), J. Clin. Chem. Clin. Biochem. 15, 353-358.

2. Oellerich, M., Haindl, H. \& Haeckel, R. (1978), Internist $19,188-190$

3. Herrmann, G. \& Aynesworth, M. B. (1937), J. Lab. Clin. Med. 23, 135-148.

4. Uauy, R., Shapiro, D. L., Smith, B. \& Warshaw, J. B. (1975), Pediatrics 55, 595-598.

5. Mitenko, P. A. \& Ogilvie, R. I. (1973), N. Engl. J. Med. $289,600-603$.

6. Kordash, T. R., van Dellen, R. G. \& McCall, J. T. (1977), J. Am. Med. Assoc. 238, 139-141.

7. Hendeles, L., Weinberger, M. \& Johnson, W. (1978), Clin. Pharmacokinet. 3, 294-312.

8. Wilson, A. F. \& McPhillips, J. J. (1978), Ann. Rev. Pharmacol. Toxicol. 18, 541-561.

9. Mangione, A., Imhoff, T. E., Lee, R. V., Shum, L. Y. \& Jusko, W. J. (1978), Chest 73, 616-622.

10. Zwillich, C. W., Sutton, Jr., F. D., Neff, T. A., Cohn, W. M. Matthay, R. A. \& Weinberger, M. M. (1975), Ann. Int. Med. $82,784-787$.

11. Giacoia, G., Jusko, W. J., Menke, J. \& Koup, J. R. (1976), J. Pediatr. 89, 829-832.

12. Ogilvie, R. I. (1978), Clin. Pharmacokinet. 3, 267-293.

13. Simons, F. E. R., Simons, K. J., Shapiro, G. G., Pièrson, W. E. \& Bierman, C. W. (1978), J. Med. 9, 81-90.

14. Weinberger, M. W., Matthay, R. A., Ginchansky, E. J., Chidsey, C. A. \& Petty, T. L. (1976), J. Am. Med. Assoc. $235,2110-2113$.
15. McDonald, J. M., Ladenson, J. H., Turk, J., Dietzler, D. N. \& Weidner, N. (1978), Clin. Chem. 24, 1603-1608.

16. Gushaw, J. B., Hu, M. W., Singh, P., Miller, J. G. \& Schneider, R. S. (1977), Clin. Chem. 23, 1144.

17. Schwertner, H. A., Wallace, J. E. \& Blum, K. (1978), Clin. Chem. 24, 360-361.

18. Standardmethode zur Bestimmung von Kreatinin in Serum oder Plasma, DIN-Entwurf 1978.

19. Haeckel, R. (1976), J. Clin. Chem. Clin. Biochem. 14, 101-107.

20. Castro, A., Ibanez, J., Voight, W., Nato, T. \& Malkus, H. (1978), Clin. Chem. 24, 944-946.

21. Tieber, V. L., Weidner, N., Smith, C. H., Kessler, G., McDonald, I. H., Ladenson, J. H. \& Dietzler, D. N. (1978), Clin. Chem. 24, 1056.

22. Chamberlain, R. T. \& Sun, L. (1978), Clin. Chem. 24, 1057.

23. Ryder, K. W., Oei, T. O., Glick, M. R., Jimerson, J. G. \& Kellog, T. L. (1978), Clin. Chem. 24, 1057.

24. Theophylline Assay EMIT-aad. Syvạ, Pạlo Alto, Cälif., 1977, p. 23.

25. Thompson, R. D., Nagasawa, H. T. \& Jenne, J. W. (1974), J. Lab. Clin. Med. 84, 584-593.

26. Sedor, F. A., Jacobson, D. L., Holleman, C. \& Cross, R. E. (1978), Clin. Chem. 24, 1057.

27. Haeckel, R. (1979), Rationalisierung des medizinischen Laboratoriums, GIT-Verlag, Darmstadt, in press.

Priv.-Doz. Dr. M. Oellerich Institut für Klinische Chemie Karl-Wiechert-Allee 9 D-3000 Hannover 61 